\title{
Effect of Breeder Age on the Progeny Performance of Three Naked-Neck Chicken Phenotypes
}

\section{EAuthor(s)}

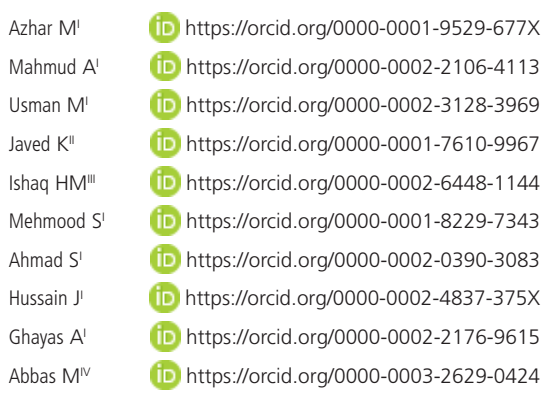

Department of Poultry Production, Faculty of Animal Production and Technology, University of Veterinary and Animal Sciences, Lahore, 54000 Pakistan.

Department of Livestock Production, Faculty of Animal Production and Technology, University of Veterinary and Animal Sciences, Lahore, 54000, Pakistan.

III Department of Livestock and Poultry Production, Faculty of Veterinary Science, Bahauddin Zakariya University, Multan, 60000, Pakistan.

v Department of Management Sciences, COMSATS Institute of Information Technology, 61100, Vehari, Pakistan.

\section{Mail Address}

Corresponding author e-mail address Muhammad Azhar

Department of Poultry Production, Faculty of Animal Production and Technology,

University of Veterinary and Animal

Sciences, Lahore, 54000, Pakistan.

Phone: +923346193770

Email: muhammad.azhar@uvas.edu.pk

\section{- Keywords}

breeder age, naked-neck chickens, progeny growth performance, varieties.

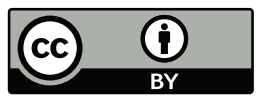

Submitted: 29/November/2018

Approved: 17/March/2019

\section{ABSTRACT}

The study was planned to evaluate the effect of different naked-neck (NN) chicken genotypes and breeder ages on the growth performance of their progenies. A total of 126 chicks, from two breeder ages and three NN varieties, were reared up to 20 weeks of age. A randomized complete block design in factorial arrangement, with six treatments of seven replicates of two females and one male each, was applied. Treatments consisted of three NN varieties (light brown, black, and dark brown) and two breeder age groups (45 and 55 weeks old). Growth performance (body weight gain, feed intake and feed conversion ratio) were evaluated. Higher feed intake was observed in both the male and female progenies of 55-week-old compared with 45-week-old breeders. Light brown males had higher weight gain than dark brown males, whereas in the female progeny, higher weight gain was obtained in the black variety than that in the light brown and dark brown varieties. Regarding breeder age groups, both male and female progenies of 55-week-oldbreeders exhibited higher weight gain than those of 45 -week-old breeders. The male progeny of 55-week-old black breeders showed the highest body weight gain among all treatments. Regarding female progeny, higher weight gain was observed in the black variety compared with the light brown and dark brown variety, and in the progeny of 55-week-old breeders than in the progeny of 45 -week-old breeders. The interaction between factors showed that females from 55 -week-old black breeder has the highest weight gain, whereas the lowest weight gain was found in the progeny of 45-week-old light brown breeders. The male progeny of light brown breeders showed better FCR than those of black and dark brown breeders and of 55-week-old breeders compared with that of 45-week-old breeders. The best FCR was obtained in the progeny of 55-week-old light brown breeders. In females, while no influence of breeder age was detected, better FCR was determined in black than in dark brown and light brown varieties; however, the interaction between factors was significant, with the best FCR obtained in the female progeny of 55-week-old black breeders, and worst in the progeny of 45-week-old light brown breeders. In conclusion, the light brown and black varieties of naked-neck chickens and the progeny of 55-week-old breeders presented better growth performance.

\section{INTRODUCTION}

During the development of the poultry industry in Pakistan, the dissemination of commercial exotic genetics was favored, while the rural germplasm remained neglected, causing the rapid depletion of native germplasm. If not conserved in time, this will ultimately destroy this excellent genetic resource. In this context, the Indigenous Chicken Genetic Resource Center (ICGRC), University of Veterinary and Animal Sciences (UVAS), Lahore, Pakistan, took the initiative to conserve the 
Azhar M, Mahmud A, Usman M, Javed K, Ishaq HM, Mehmood S, Ahmad S, Hussain J, Ghayas A, Abbas M
Effect of Breeder Age on the Progeny Performance of Three Naked-Neck Chicken Phenotypes local gene pool, maintaining specimens of pure nakedneck (NN) varieties, which is one of the most important native chicken breeds in Indo-Pak subcontinent. In historical perspective, NN breeds originated from Hungary and were improved in Germany (Grobbelaar et al., 2010). In NN chickens, the Na gene is responsible for featherless neck, which helps chickens to tolerate hot climatic conditions (Okeno et al., 2011). The Na gene is mainly responsible for low feed intake, good disease resistance, high weight gain and dressing percentage, and adaptation to high environmental temperatures (Ajayi, 2010). Moreover, this amazing bird has superior egg production and egg quality than other native breeds of Pakistan (Usman et al., 2014). Similarly, another study reported that NN chickens mature earlier than normal-feathered chickens (Ibe, 1992). In addition, the Na gene has been associated with higher laying rate, egg size and egg mass in hot weather compared with dwarf and rapid-feathering genes (Younis \& Galal, 2006). The annual egg production of naked-neck hens is about 138 eggs (Grobbelaar et al., 2010). Due to these attributes, the rural population prefer to rear naked-neck chickens as source of meat and eggs.

In Pakistan, there are four varieties of NN chickens, including light brown, dark brown, black and white feathers with a black tip (Shafiq, 2017). Males and females of all phenotypes have plain head and single comb, with medium-size wattles in females and highlydeveloped wattles in males. Overall, the plain feather pattern is predominant in the breast, wing bow, wing bar, wing bay, saddle and tail, followed by stippled, penciled and laced feathers (Iqbal et al., 2015). Males commonly have yellow shanks, and sometimes grey, off-white and green shanks, whereas most females have grey shanks, followed by yellow, green and offwhite shanks. Morphometric measurements such as keel and shank length, shank width, and breast angle and width also vary between sexes and higher values are obtained in males than in females (Mahrous \& Radwan, 2011).

In poultry, breeder stock age is the main determinant of subsequent chick performance, weight gain and carcass traits. At their prime age of production, breeder stock produce chicks that perform better than those produced by breeders at the end of the production phase. The effect of breeder age on chick quality has been widely investigated in commercial poultry strains (Peebles et al., 1999; Ulmer-Franco et al., 2010; El-Sabry et al., 2015). However, in native naked-neck chickens, there is no information on the effect of breeder age on subsequent chick performance. The optimization of breeder age of indigenous chicken breeds to obtain better chick quality and growth is still a major challenge in rural poultry production in Pakistan and needs to be further explored. Therefore, the present study was designed to determine the effect of breeder age (45 and 55 weeks old) on subsequent progeny growth of three varieties (light brown, dark brown and black) of naked-neck chickens.

\section{MATERIALS AND METHODS}

\section{Bird management}

Experimental birds were purchased from a hatchery at Avian Research and Training (ART) Center, UVAS, Lahore, Pakistan. The experimental birds derived from 45- or 55-week-old breeders. Chicks were individually weighed and tagged at hatchery (Figure 1).

Day-old chicks were transported in cardboard boxes from the ART Center to the ICGRC, UVAS, Ravi Campus Pattoki, Pakistan. Birds were kept in a wellventilated, semi-controlled environment poultry house, and submitted to standard husbandry practices.

Birds were given an adaptation period of three days and subsequently housed in battery cages ( 3 males
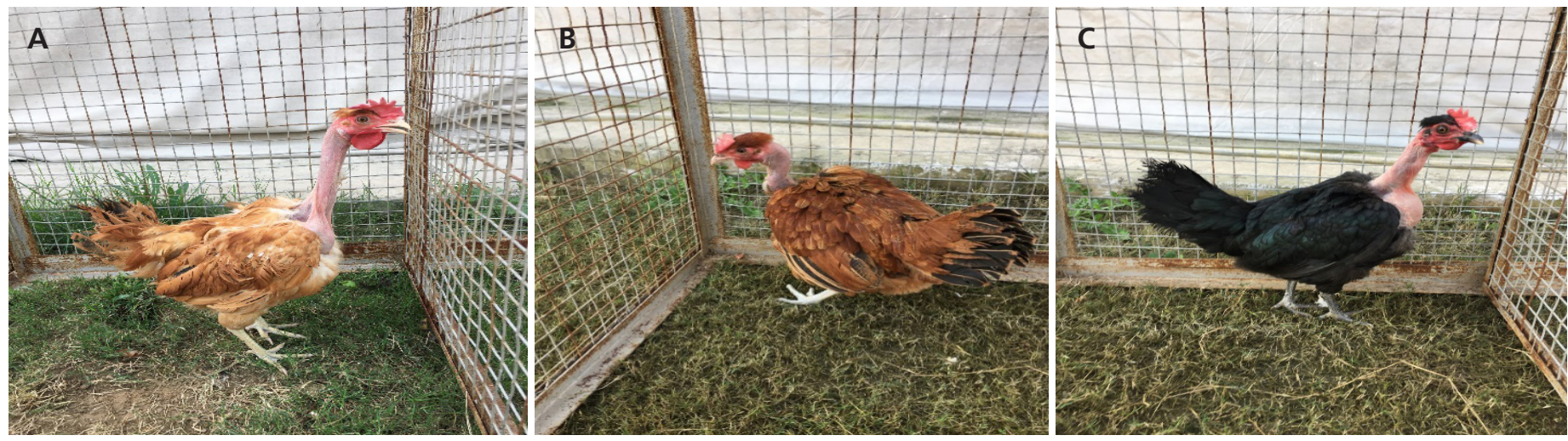

Figure 1 - Naked-neck chicken varieties; A: light brown; B: dark brown; C: black. 
Azhar M, Mahmud A, Usman M, Javed K, Ishaq HM, Mehmood S, Ahmad S, Hussain J, Ghayas A, Abbas M
Effect of Breeder Age on the Progeny Performance of Three Naked-Neck Chicken Phenotypes and 6 females per cage) equipped with trough feeders and a nipple drinking system. At the hatchery, all the birds were vaccinated against Newcastle Disease and Infectious Bronchitis, according to the local area schedule. From the start of experiment, light was provided by sunlight exposure until the start of lay (approximately 8 hours). Regular supply of fresh and clean drinking water was ensured through nipple drinker system. Birds were offered a commercial feed throughout the experimental period. The feed was formulated (Table 1) according to the recommendations of the NRC (1994).

Table 1 - Nutrient composition of experimental feeds for different phases.

\begin{tabular}{lccc}
\hline Nutrients & $\begin{array}{c}\text { Starter } \\
\text { (0-6 weeks) }\end{array}$ & $\begin{array}{c}\text { Grower } \\
(7-16 \text { weeks })\end{array}$ & $\begin{array}{c}\text { Developer } \\
(17-20 \text { weeks })\end{array}$ \\
\hline CP (\%) & 17 & 16 & 14 \\
ME $(\mathrm{kcal} / \mathrm{kg})$ & 2850 & 2900 & 2850 \\
$\mathrm{Ca}(\%)$ & 0.90 & 0.90 & 0.87 \\
Av. P (\%) & 0.40 & 0.40 & 0.38 \\
Lysine (\%) & 0.80 & 0.80 & 0.70 \\
Methionine (\%) & 0.28 & 0.33 & 0.30 \\
\hline
\end{tabular}

\section{Experimental design and evaluated parameters}

At 20 weeks of age, live performance quantitative parameters were evaluated. For this purpose, a total of 126birds (42 males and 84 females) were distributed in a randomized complete block design in a $3 \times 2$ factorial arrangement. The six treatments consisted of NN chickens of three varieties (light brown, dark brown, or black) and two breeder ages (45 or 55 weeks old), with seven replicates of three birds in each ( 2 males and 1 male).

The performance parameters body weight gain (BWG), feed intake (FI), and feed conversion ratio (FCR) were recorded for the duration of 20 weeks, from March to July of 2017. Individual body weight gain was weekly recorded and calculated by subtracting body weight measured at the end of each week from initial body weight. Feed intake was recorded on daily basis and calculated by subtracting feed offer from residual feed. Weekly feed conversion ratio was calculated dividing feed intake by body weight gain.

\section{Statistical Analysis}

The effects of breeder ages and NN varieties on progeny $\mathrm{FI}, \mathrm{BWG}$, and FCR were analyzed by factorial analysis of variance, using the PROC GLM of SAS software (version 9.1). Breeder ages and NN varieties were considered as main effects, and their interaction was also tested. All the parameters were analyzed separately for the male and female progeny. Significant treatment means were compared by Tukey's HSD test at $5 \%$ probability level, assuming following mathematical model. Each cage was considered as experimental unit.

Yijk $=\mu+\beta i+\tau j+(\beta i \times \tau j)+\varepsilon i j k$

Where,

$Y_{i, k}=$ Observation of dependent variable recorded on $\mathrm{j}^{\text {th }}$ breeder age in ithblock

$\mu=$ population mean

$\beta=$ effect of $i^{\text {th }}$ block (variety: $i=1,2,3$ )

$\tau_{i}=$ Effect of $j^{\text {th }}$ Breeder Age $(j=1,2)$

$\left(\beta_{i} \times \tau_{j}\right)=$ Interaction between block and breeder age

$\varepsilon_{i j k}=$ Residual effect of the $k^{\text {th }}$ observation on the $j^{\text {th }}$ treatment in thei ${ }^{\text {th }}$ block NID $\sim 0, \sigma^{2}$

\section{RESULTS AND DISCUSSION}

\section{Feed intake}

Feed intake results are shown in Table 2. In the present study, both the male and female progenies of 55-week-old breeders presented higher feed intake $(p=0.0134)$ compared with those of 45 -week-old breeders. This difference in feed intake is consistent with the findings of Sabry et al. (2015), who observed lower $\mathrm{Fl}$ in broilers from 32-week-old breeders compared with those of 49-week-old breeders. On the other hand, non-significant FI differences were reported in broilers from breeders of different ages, revealing no association between breeder age and progeny feed intake (Franco et al. 2010). In a study with Japanese quails, feed intake did not significantly differ among the progenies of 10-, 12- and 14-weekold breeders (Ahmad et al., 2018). In the present study, cumulative average feed intake (20 weeks) of both male and female progenies did not differ among varieties $(p=0.2919)$ and no interaction of sex with breeder age was detected ( $p=0.8878$ ). However, Shafiq et al. (2018) observed that naked-neck white black phenotype females consumed more feed than light brown, dark brown, and black phenotype females.

\section{Body Weight Gain}

The BWG results obtained are shown in Table 2 and Figures 2, 3, 4, and 5.

When considering the main effect of genotype, higher BWG was achieved in light brown males had than dark brown males (1393 vs. $1275.86 \mathrm{~g} ; p$ $=0.0076)$, whereas in the female progeny, higher BWG was obtained in the black than in light brown and dark brown genotype (1150.14 vs. 1070.07 
Azhar M, Mahmud A, Usman M, Javed K, Ishaq HM, Mehmood S, Ahmad S, Hussain J, Ghayas A, Abbas M
Effect of Breeder Age on the Progeny Performance of Three Naked-Neck Chicken Phenotypes

Table 2 - Effect of two Breeder Ages on Progeny Growth (20 weeks) among three varieties of naked-neck chickens.

\begin{tabular}{|c|c|c|c|c|c|c|c|}
\hline \multirow{2}{*}{\multicolumn{2}{|c|}{ Variety }} & \multicolumn{2}{|c|}{ Feed Intake (g) } & \multicolumn{2}{|c|}{ Weight Gain (g) } & \multicolumn{2}{|c|}{ FCR (feed/gain) } \\
\hline & & Males & Females & Males & Females & Males & Females \\
\hline \multicolumn{2}{|l|}{ Light brown } & $4324.65 \pm 16.69$ & $4324.65 \pm 16.69$ & $1393.00^{\mathrm{a}} \pm 27.60$ & $1070.07^{b} \pm 19.84$ & $3.11^{\mathrm{b}} \pm 0.06$ & $4.08^{a} \pm 0.08$ \\
\hline \multicolumn{2}{|l|}{ Black } & $4319.08 \pm 14.64$ & $4319.08 \pm 14.64$ & $1315.21^{\mathrm{ab}} \pm 50.76$ & $1150.14^{a} \pm 20.77$ & $3.37 \mathrm{a} \pm 0.14$ & $3.79^{b} \pm 0.07$ \\
\hline \multicolumn{2}{|l|}{ Dark brown } & $4293.26 \pm 14.48$ & $4293.26 \pm 14.48$ & $1275.86^{b} \pm 24.92$ & $1063.68^{b} \pm 13.25$ & $3.39^{\mathrm{a}} \pm 0.06$ & $4.06^{a} \pm 0.06$ \\
\hline \multicolumn{8}{|c|}{ Breeder age } \\
\hline \multicolumn{2}{|l|}{45 weeks } & $4290.46^{b} \pm 10.49$ & $4290.46^{\mathrm{b}} \pm 10.49$ & $1274.57^{b} \pm 25.54$ & $1070.20^{\mathrm{b}} \pm 12.49$ & $3.42^{\mathrm{a}} \pm 0.08$ & $4.03 \pm 0.05$ \\
\hline \multicolumn{2}{|l|}{55 weeks } & $4334.20^{\mathrm{a}} \pm 13.57$ & $4334.20^{\mathrm{a}} \pm 13.57$ & $1381.48^{\mathrm{a}} \pm 31.86$ & $1119.05^{a} \pm 18.16$ & $3.15^{b} \pm 0.07$ & $3.92 \pm 0.07$ \\
\hline \multicolumn{8}{|c|}{ Variety $\times$ Breeder age (weeks) } \\
\hline \multirow{2}{*}{ Light brown } & 45 & $4306.54 \pm 14.73$ & $4306.54 \pm 14.73$ & $1327.86^{\mathrm{ab}} \pm 28.86$ & $1033.29^{b} \pm 22.35$ & $3.25^{b c} \pm 0.08$ & $4.20^{a} \pm 0.10$ \\
\hline & 55 & $4342.75 \pm 29.82$ & $4342.75 \pm 29.82$ & $1458.14^{\mathrm{a}} \pm 32.48$ & $1106.86^{a b} \pm 30.46$ & $2.97 \_ \pm 0.07$ & $3.96^{\mathrm{ab}} \pm 0.12$ \\
\hline \multirow{2}{*}{ Black } & 45 & $4299.34 \pm 18.48$ & $4299.34 \pm 18.48$ & $1167.86^{c} \pm 37.14$ & $1096.50^{b} \pm 25.27$ & $3.76^{\mathrm{a}} \pm 0.14$ & $3.95^{\mathrm{ab}} \pm 0.09$ \\
\hline & 55 & $4338.81 \pm 22.12$ & $4338.81 \pm 22.12$ & $1462.57^{a} \pm 50.49$ & $1203.79^{a} \pm 26.66$ & $2.98 \div \pm 0.09$ & $3.63^{b} \pm 0.09$ \\
\hline \multirow{2}{*}{ Dark brown } & 45 & $4265.50 \pm 20.22$ & $4265.50 \pm 20.22$ & $1328.00^{\mathrm{ab}} \pm 38.24$ & $1080.86^{b} \pm 13.08$ & $3.27^{b c} \pm 0.10$ & $3.95^{\mathrm{ab}} \pm 0.05$ \\
\hline & 55 & $4321.02 \pm 18.54$ & $4321.02 \pm 18.54$ & $1223.71^{\mathrm{bc}} \pm 17.97$ & $1046.50^{b} \pm 22.65$ & $3.50^{\mathrm{ab}} \pm 0.05$ & $4.16^{\mathrm{a}} \pm 0.10$ \\
\hline \multicolumn{8}{|c|}{$p$-value } \\
\hline \multicolumn{2}{|l|}{ Variety } & 0.2919 & 0.2919 & 0.0076 & 0.0007 & 0.0086 & 0.0042 \\
\hline \multicolumn{2}{|l|}{ Breeder age } & 0.0134 & 0.0134 & 0.0008 & 0.0149 & 0.0010 & 0.1364 \\
\hline \multicolumn{2}{|l|}{ Variety $\times$ Breeder age } & 0.8878 & 0.8878 & $<.0001$ & 0.0114 & $<.0001$ & 0.0155 \\
\hline
\end{tabular}

a-cMeans followed by different superscripts in the same column indicate significant difference $(p \leq 0.05)$.

\& $1063.68 \mathrm{~g} ; p=0.0007)$. Regarding the effect of breeder age, both the male (1381.48 vs. 1274.57 $\mathrm{g} ; p=0.0008)$ and female (1119.95 vs. $1070.20 \mathrm{~g}$; $p=0.0149$ ) progenies of 55-week-oldbreeders gained more weight compared with 45-week-oldbreeders. A significant interaction between genotype and breeder age was detected for the BWG of both the male and female progenies. Males from55-week-oldblack and light brown breeders presented the highest BWG and those from 45-week-old black breeders, the lowest BWG (1462.57 vs. 1167.86 g; $p<0.0001$ ), whereas in females, the highest BWG was observed in the progeny of 55-week-old black breeders and the lowest in the progeny of 45 -week-old light brown breeders (1203.79 vs. $1033.29 \mathrm{~g} ; p=0.0114$ ). These results are consistent with those of Braun et al. (2002), who also observed a positive trend between duckling body weight and breeder age and reported that the

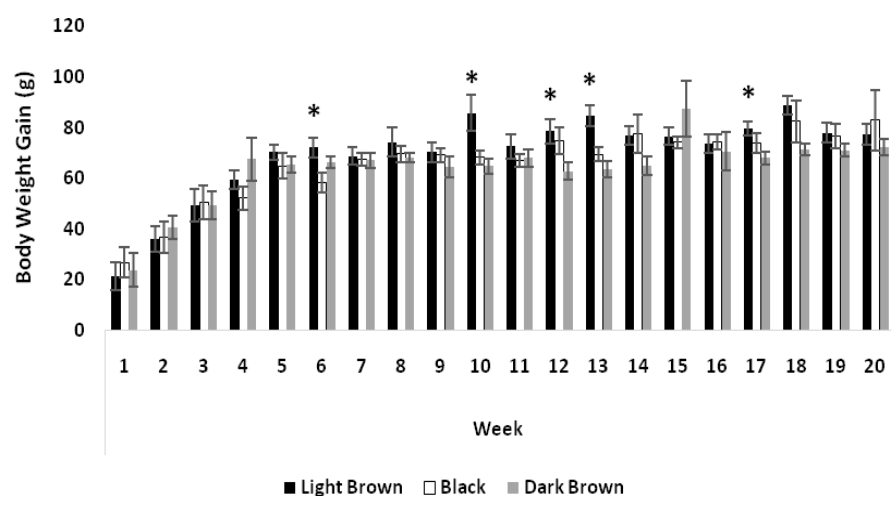

Figure $\mathbf{2}$ - Trend of weekly body weight gain of the male progenies of three naked-neck chicken varieties; ${ }^{*}$ Significant at $p \leq 0.05$. offspring of young breeders (24 weeks old) grew at a slower rate after hatch compared with ducklings of breeders of intermediate (31 weeks old) and older ages (47 weeks old). However, Ahmad et al. (2018) reported higher weight gain in the progeny from young Japanese quail breeders (10 weeks old) than those from 12- and 14-week-old breeders. The higher body weight of the progeny of older breeders may be attributed to the higher egg weight laid, resulting in heavier hatchling weight, which was probably was sustained during later ages. Relative to the effect of naked-neck genotype, Pavlovski et al. (2009) also found significant BWG differences among naked-neck chicken varieties, with higher values obtained in white than in gray and black varieties. Furthermore, Shafiq et al. (2018) reported higher $(p \leq 0.05)$ body weight in light and dark brown compared with black and white naked-neck phenotypes.

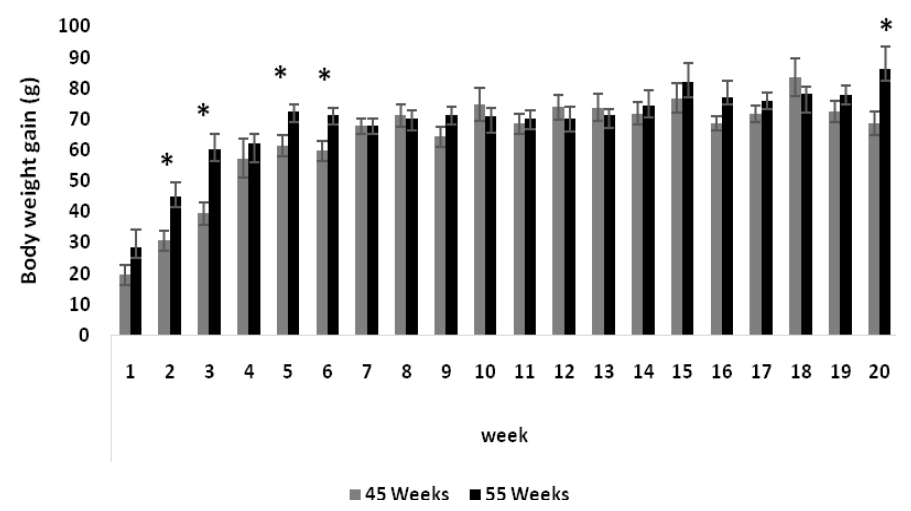

Figure 3 - Trend of weekly body weight gain of the male progenies of 45 - and 55-week-oldbreeders; * Significant at $p \leq 0.05$. 
Azhar M, Mahmud A, Usman M, Javed K, Ishaq HM, Mehmood S, Ahmad S, Hussain J, Ghayas A, Abbas M

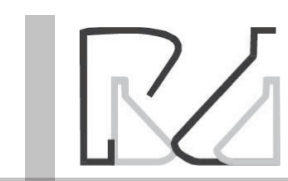

Effect of Breeder Age on the Progeny Performance of Three Naked-Neck Chicken Phenotypes

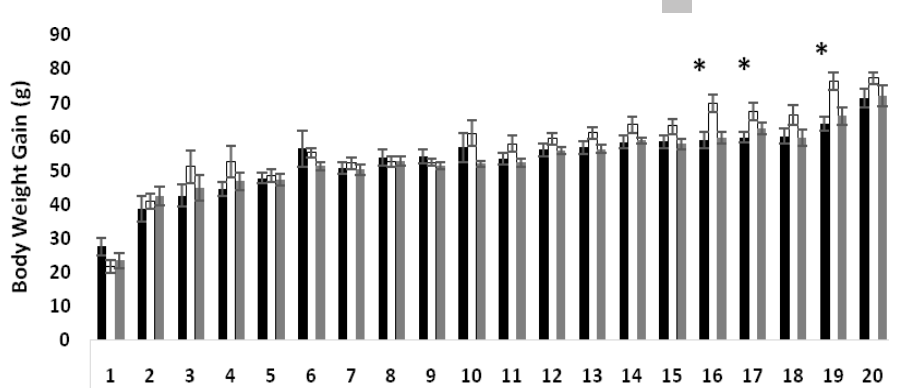

Week

- Light Brown $\square$ Black $\quad$ Dark Brown

Figure 4 - Trend of weekly body weight gain of the female progenies of three naked-neck chicken varieties; * Significant at $p \leq 0.05$.

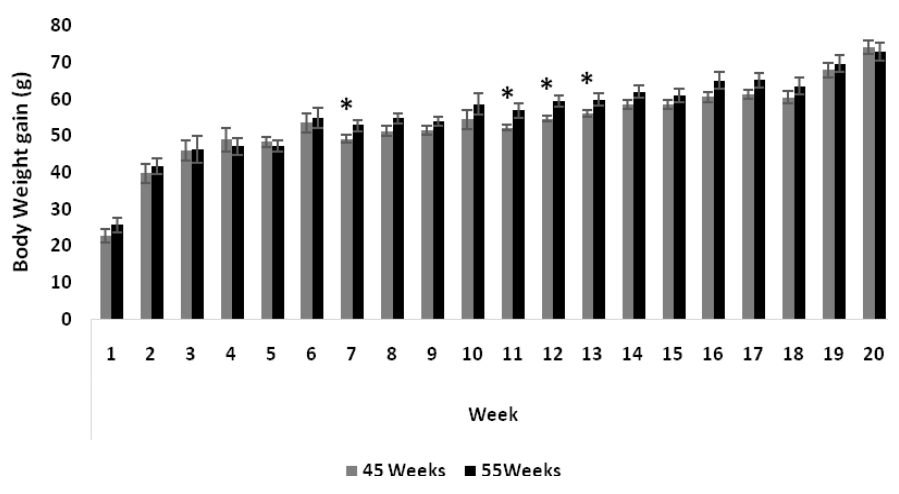

Figure $\mathbf{5}$ - Trend of weekly body weight gain of the female progenies of 45 - and 55-week-old breeders; * Significant at $p \leq 0.05$.

\section{Feed Conversion Ratio}

The feed conversion ratio (FCR) results are shown in Table 2 and Figures 6, 7, 8, and 9.

Phenotype affected the FCR of both the male and female progenies. Light brown males showed better FCR than black and dark brown males (3.11 vs. $3.37 \& 3.39 ; p=0.0086)$, whereas better FCR was obtained in black than in dark brown and light brown females (3.79 vs. $4.06 \& 4.08 ; p=0.0042$ ). Breeder age significantly influenced the FCR of the male progeny, with better FCR obtained in males from 55-weekold breeders compared with those of 45-weekoldbreeders ( 3.15 vs. $3.42 ; p=0.0010$ ). However, the main effect of breeder age on the FCR of females was not significant $(p=0.1364)$. Significant interactions between phenotype and breeder age for FCR of both male and female progenies were observed. In males, the best FCR was obtained in the progeny of 55-weekoldlight brown breeders, whereas the poorest FCR was observed in the progeny of 45-week-oldblack breeders (2.97 vs. 3.76; $p<.0001)$. Relative to females, the progeny of 55-week-old black breeders presented the best FCR, while the poorest FCR was recorded in the progeny of 45 -week-old light brown breeders (3.63 vs. 4.20; $p=0.0155)$. These findings are in agreement with previous published studies. Peebles et al. (1999) found a positive association between breeder age and FCR of the progeny. Similarly, FCR improvements were also reported with the advancement of breeder age in Japanese quails (Ahmad et al., 2018). In the study of Amao (2017), naked-neck chickens showed better FCR relative to Rhode Island Red birds. Evaluating four varieties of Aseel chickens, Jatoi et al. (2014) found that the average FCR were significantly among phenotypes at 1, 4, 5, 8, 9, and 11 weeks of age. Those authors observed the highest average FCR in Lakha and Mianwali varieties $(6.52 \pm 0.66$ and $6.62 \pm 0.43$, respectively) in week 13 and in Mushki and Peshawari (6.54 \pm 0.6 and $7.70 \pm 3.4$, respectively) in weeks 2 and 7 , while the lowest average FCR were recorded in Lakha, Mianwali, Mushki and Peshawari $(3.1 \pm 0.16,2.96 \pm 0.2$, $2.91 \pm 0.13,3.7 \pm 0.32$, respectively) in week 1 .

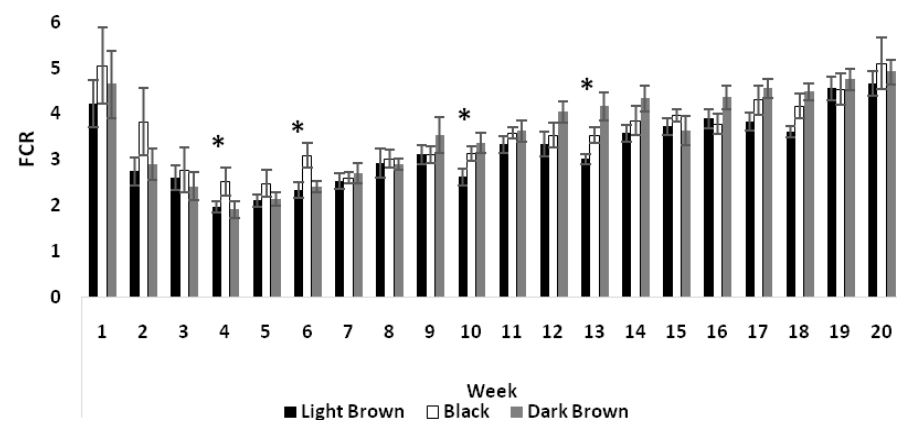

Figure $\mathbf{6}$ - Trend of weekly FCR of the male progenies of three naked-neck chicken varieties; * Significant at $p \leq 0.05$.

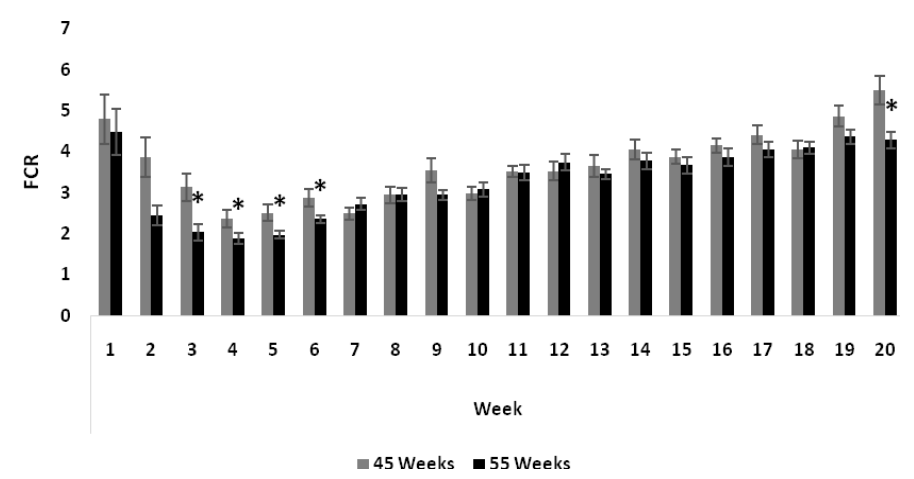

Figure 7 - Trend of weekly FCR of the male progenies of 45- and 55-week-old breeders; * Significant at $p \leq 0.05$.

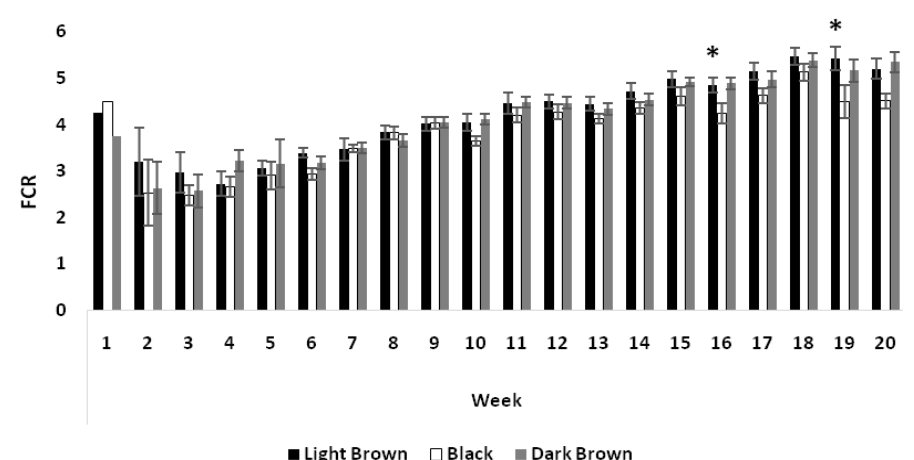

Figure $\mathbf{8}$ - Trend of weekly FCR of the female progenies of three naked-neck chicken varieties; * Significant at $p \leq 0.05$ 


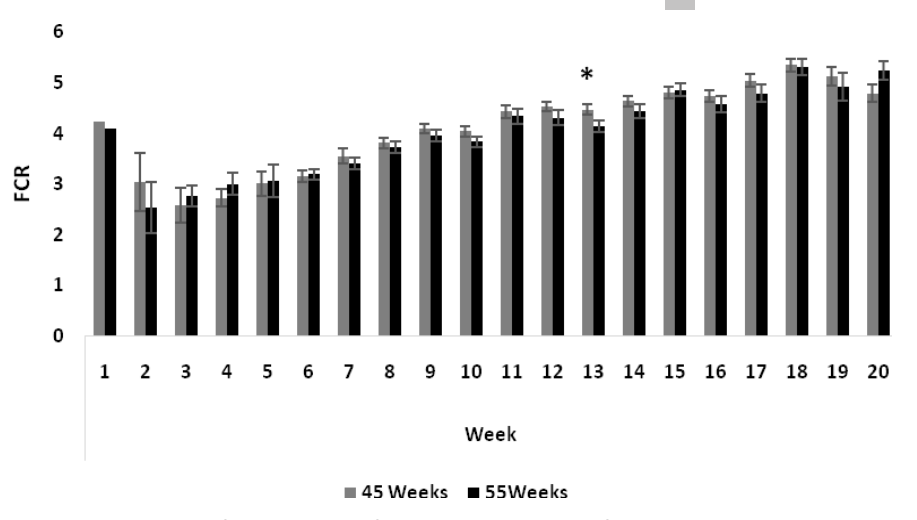

Figure 9 - Trend of weekly FCR of the male progenies of 45 - and 55-week-old breeders; * Significant at $p \leq 0.05$

\section{CONCLUSIONS}

The results of this study showed that the light brown and black varieties of naked-neck chickens present higher weight gain and better FCR than the dark brown variety, and that the progeny of 55-weekoldbreeders have better growth performance than that of 45-week-old breeders.

\section{ACKNOWLEDGEMENTS}

This project was funded by Pakistan Agriculture Research Council, ALP, Project No. AS-135. Authors gratefully acknowledged the contributions made by Administration at Indigenous Chicken Genetic Resource Centre, Department of Poultry Production, University of Veterinary and Animal Sciences, Lahore, Pakistan.

\section{CONFLICT OF INTEREST DECLARATION}

No potential conflict of interest was found by the authors.

\section{REFERENCES}

Ahmad S, Mehmood S, Javed K, Mahmud A, Usman M, Rehman A, et al. Different selection strategies for the improvement of the growth performance and carcass traits of Japanese quail. Brazilian Journal of Poultry Science 2018;20(3):497-506.

Ajayi FO. Nigerian indigenous chicken: A valuable genetic resource for meat and egg production. Asian Journal of Poultry Science 2010;4(4):164172.

Amao SR. Egg production and growth performance of naked-neck and Rhode Island Red chickens crosses under southern guinea savanna condition of Nigeria. International Journal of Agriculture and Earth Science $2017 ; 3(2): 1-10$.

Braun CM, Neuman S, Hester PY, Latour MA. Breeder age alters offspring performance in the Pekin duck. Journal of Applied Poultry Research $2002 ; 11: 270-274$.
El-Sabry MI, Yalçin S, Turgay-Izzetoğlu G. Effect of breeder age and lighting regimen on growth performance, organ weights, villus development, and bursa of fabricius histological structure in broiler chickens. Czech Journal of Animal Science 2015;60(3):116-122.

Grobbelaar JAN, Sutherland B, Molalakgotla NM. Egg production potentials of certain indigenous chicken breeds from South Africa. Animal Genetics Resources 2010;46:25-32

Ibe SN. Incorporating adaptability genes in poultry breeding programmes in Nigeria. Proceedings of the $18^{\text {th }}$ World's Poultry Congress; 1992; Nagoya. Japan.

Iqbal A, Ali A, Javed K, Akram M, Usman M, Mehmood S, et al. Phenotypic characterization of two indigenous chicken ecotypes of Pakistan. Journal of Animal and Plant Sciences 2015;25(2):346-350.

Jatoi AS, Iqbal M, Sahota AW, Akram M, Javed K, Jaspal MH, et al. Comparative growth performance in four varieties of native Aseel chickens maintained in Pakistan. Pakistan Journal of Zoology 2014;46(6):1565-1571.

Mahrous MY, Radwan LM. Impact of Naked-Neck (Na) gene, sex and their interactions on live growth performance and carcass characteristics of broiler chicks under summer season of Egypt. Egyptian Poultry Science 2011;31(4):845-853.

National Research Council. Nutrient requirements of poultry. Washington: National Academy Press; 1994

Okeno TO, Kahi AK, Peters JK. Characterization of indigenous poultry production systems in Kenya:household flock structure, dynamics and breeding practices. Tropical Animal Health Production 2011;44(3):601608.

Pavlovski Z, Skribic Z, Lukic M, Vitrovic D, Petricevic V, Milosevic N. nakedneck chickens of Serbian and foreign origin carcass characteristics. Biotechnology Animal Husbandry 2009;25(5/6):1023-1032.

Peebles, ED, Doyle SM, Pansky T, Gerard PD, Latour MA, Boyle CR, et al. Effects of breeder age and dietary fat on subsequent broiler performance. 2. Slaughter yield. Poultry Science 1999;78:512-515.

Shafiq M. Comparative phenotypic characterization, performance and antibody response in naked-neck chicken [PhD thesis]. Lahore (PAK): University of Veterinary and Animal Science; 2017

Shafiq M, Mahmud A, Hussain J, Basheer A, Mehmood S, Khan MT, et al. Comparative production performance of four different naked-neck chicken phenotypes in Pakistan. Journal of Animal Plant Sciences 2018;28(1):33-37

Ulmer-Franco AM, Fasenko GM, O'Dea Christopher EE. Hatching egg characteristics, chick quality, and broiler performance at 2 breeder flock ages and from 3 egg weights. Poultry Science 2010;89:2735-2742.

Usman M, Zahoor I, Basheer A, Akram M, Mahmud A. Aseel chicken - a preferable choice for cost-effective and sustainable production of meattype poultry in the tropics. Science International 2014;26(3):13011306

Younis HH, Galal A. Impact of Dwarf $(\mathrm{dw})$, rapid feathering $(\mathrm{K}+)$ and NakedNeck genes on growth and egg production of laying hen chickens. Egyptian Poultry Science 2006;26:17-38. 